\title{
Using songs to improve students' pronunciation
}

\author{
Nur Laili Rizky Rahmawati ${ }^{1}$, Muhammad Yunus ${ }^{2}$ \\ ${ }_{1,2,}^{2}$ Fakultas Keguruan dan Ilmu Pendidikan, Universitas Islam Malang, Indonesia \\ 1ailyrizky06@gmail.com,²m.yunus@unisma.ac.id \\ *) correspondence: lailyrizky06@gmail.com
}

\begin{abstract}
This research was designed to improve students' pronunciation at MTs Almaarif 01 Singosari, Malang through songs. In the preliminary study, the researcher found that the students have trouble pronouncing words correctly and confirmed by the result of their English test in oral test that was 57.20. Besides 43 students were taken in VIII A class at MTs Almaarif 01 Singosari, Malang as the sample of the study, this research consists of two cycles; Cycle One with three meetings and Cycle Two with two meetings. In the planning stage, the researcher designed a lesson plan, preparing material, and formulating the criteria of success. The criteria of success that was 70 or more. Additionally, the first result of Cycle One got 63.25. At the final, the result of Cycle Two showed another increase, there were 71.16. In the research finding, it is concluded that the use of songs in teaching pronunciation can improve the pronunciation of the students. All in all, for the teacher should give English songs according to their level; beginner, intermediate, or advanced, for students are suggested to choose other genre of the song for their learning media, such as jazz, rock, and etc. For future researchers are suggested to conduct similar studies on using songs in a different context, subject, or method.
\end{abstract}

Keywords: Improving; pronunciation; song

\section{INTRODUCTION}

A song consists of two aspects, those are lyric and elements; such as rhythm, melody, harmony, and expressions (Primandaru, 2013). Pronunciation according to Merriam Webster (2019) is how a word or name is pronounced. Related to this issue, Hornby (1995) as cited in Samir (2017) defined that pronunciation is a way of conveying words to someone. Based on those definitions, it can be concluded that pronunciation is how a language is spoken, how a word is spoken, and the way someone pronounces words in language.

English pronunciation is one of the factors that influence teaching in students' speaking skills. In this case, the teachers have to select the media that is suitable to be applied in teaching English pronunciation. In addition, they are also hope to know how to teach pronunciation well by knowing a good way of teaching English pronunciation.

In this research, the researcher has been made observations during her fieldwork in JulySeptember 2018 in the VIII A students at MTs Almaarif 01 Singosari, Malang. They tended to have problems pronouncing when the researcher asked them to read the text given. Besides the researcher evidenced the average score of students in terms of their pronunciation that was 57.20 , so learning pronunciation is not easy for students. To make it easy in delivering the materials, the teacher needs media, such as songs.

The song lyrics can help the students to acquire their language. The authors of song lyrics especially compose song lyrics for teenagers. It means that the intonation and forms in song lyrics are easy to be understood by teenagers. Philips (1993) as cited in Manik (2015) stated that music is a tool most easily imitated by people. And based on that reason, teenagers will try to do any efforts to 
know much about the songs. If the teenagers have a willing to know the songs, they will try to learn anything related to the songs.

Moreover, learning English through songs can be improve to assist pronunciation, since the students can directly get the knowledge on how to pronounce the word from the song they hear when students learn in an enjoyable situation, they will understand the lesson easily, from the reason above, the researcher decided to make the research entitled "Improving Students' Pronunciation Ability Through Songs for the Second-Grade at MTs Almaarif 01 Singosari, Malang."

Song is the act or art of singing (Merriam Webster, 2019). Generally, song as known as music consists of two elements, sounds as the primary and lyrics as the secondary (Yuningsih, 2018). Mena (2015) as cited in Castro (2014) said that students can find easy ways to learn songs by making connections with their lives and social reality. Using songs in a social context can also encourage the students to learn English and involve student involvement in the teaching and learning process. Morales (2008) stated in Sumantri 2011) said that students can enlarge their involvement in using meaningful duties through the use of authentic materials such as rock songs to express their opinions, feelings, and reactions.

Songs for intermediate level could be used interpretative songs and interpret the message. But not all songs are suitable for their level and some may be difficult; some may have inappropriate themes for teachers to use it. Lems (2005) said that the key points are that the teachers love the song and want to teach students with it. Therefore, if the teachers love the song, chances are most of the students will have big excited for the songs that their teachers' selection. It can be easy for the teachers to carry on the lessons deeply and emotionally.

\section{METHODS}

The subject of this research was VIII Aclass consist of 43 students at MTs Almaarif 01 Singosari, Malang. The procedure of this Classroom Action Research is conducted in cycles which consist of five steps. They are; preliminary study, planning included designing lesson plan, preparing material, preparing criteria of success, implementing, observation checklist, field notes, testing, and reflecting the study. The researcher used field note and observation checklist to find out the class atmosphere and the attention of students to the material that given by the researcher.

The test is speaking. There was two song entitled I Have A Dream by Westlife in cycle one and Insha Allah by Maher Zain in cycle two that determined whether the students are successful or not. The students have to come one by one and chose paper rolls that have been randomized by the researcher. In the paper rolls, there are song lyrics pieces of a song that has been heard by students. The students have to read song lyrics pieces. However, this cycle stop if the average of students' scores can achieve the criteria of success that is 70 or above if the result of the test is not a success, the researcher should change the next plan and continue to the next cycle until the result of the test is successful to the criteria of success that is 70 or above.

\section{RESULTS AND DISCUSSION}

\section{Cycle One}

\section{Meeting One}

In the first meeting, the researcher was playing the song entitled I Have a Dream by Westlife. The field note mentions that the students looked enthusiastic and happy because they learned by using the song even though they don't know the song.

\section{Meeting Two}

The students were asked to sing the last song that has been learned before entitled I Have a Dream by $W$ estlife. The researcher and the students sing together with karaoke version. The researcher asked the students what the song about. Almost all students raised their hands but seemed hesitant in giving their answers. 
Next, the researcher invited some students to perform the song in front of the class. This made the situation in the classroom alive because they cheered each other to see their friend come to the front of the class.

\section{Meeting Three}

The researcher called one by one name stated in the attendance list and students take one roll of paper. The researcher gave 90 seconds per student; there were 43 students. Thus, the time needed was 60 minutes. Based on the result of the students' pronunciation score in cycle one that was 63.25 .

\section{Reflection}

Some improvement was made by using a song in teaching and learning activities like the joyful learning atmosphere. The improvement was proven by the comparison between the score of preliminary study and the score of a test in Cycle One. The average score of preliminary study is 57.20, while in Cycle One, the students got 63.25 for the average score. However, the researcher had not yet achieved the criteria of success (70.00). There were some aspects of teaching and learning strategies to be improved. Based on the explanation above, some steps in the first cycle need to be improved.

\section{Cycle Two}

\section{Meeting One}

The researcher introduced a new song, entitled Insha Allah by Maher Zain. The students are very enthusiastic because the song they are heard is a song that familiar with them.

Next, the researcher played the game, the game was the student who had been appointed by the researcher to come forward and sing the song entitled Insha Allah by Maher Zainin front of the class, after that she and he had the right to appoint his and her friends to sing in front of class too. There are six students come to in front class and sing the song.

Here, it appears that students are very enthusiastic to the game because they are very interested in that song. It was also seen that the atmosphere in the day was very lively.

\section{Meeting Two}

The researcher asked the students to take one roll of paper and come to the researcher one by one based on the attendance list. The researcher gave 90 seconds per student; there were 43 students. Thus, the time needed was 60 minutes. In the Cycle Two the students got an average score of about 71.16.

\section{Reflection}

In Cycle Two, the researcher successfully achieved the criteria for success. In this research, the researcher targeted that there was 70 for criteria of success and the students got score 71.16. Based on this development, the researcher had achieved the criteria for success.

The section presents the discussion of the ways students can improve their ability in English pronunciation at MTs Almaarif 01 Singosari, Malang. The result in Cycle One showed that students got a score of 63.25. In Cycle Two the students got 71.16. So, the song Insha Allah by Maher Zain successfully increased the pronunciation of students in VIII A class at MTs Almaarif 01 Singosari, Malang.

There are some important points which should be discussed concerning the use of songs and several roles of the songs which influence the students' pronunciation. Before the research was implemented, the students encountered many difficulties to pronounce. One main problem was that the students tend to read words like a mother tongue. In VIII A class students at MTs Almaarif 01 Singosari, Malang, some students are still having a problem in reading words correctly, such as the pronunciation that differs from the writing. Thus, the researcher used the song to overcome the students' problems. The use of songs was found that improving students' pronunciation ability. The song was selected by considering the students' relevance to the curriculum and the lesson program. 
Moon (2000) as cited in Heslinga (2012) stated that the activities that are related to the topic or theme, helps the students to learn and practice the language. In accordance with this point, the researcher selected the appropriate song for learners. Some points contribute to the success of the strategies.

In the first activity, the researcher distributed a piece of paper consisting of a song lyric

entitled I Have A Dream byWestlifeas a learning process in improving pronunciation. The second activity has explained by the researcher the meaning of the song and the researcher played the song using audio to introduce how pronouncing the lyrics of the song. The purpose of knowing the meaning of the song was the students more easily imitated the song with their feelings. Next, the students just purely listen, which aimed that the students know the pronunciation of the song from the singer and make it easier for students to practice the lyric of pronunciation. Second, singing with audio, aimed to train students to apply the pronunciation of the lyrics. The last one singing without

using audio aimed to evaluate the extent to which students can imitate the pronunciation of the song. The last activity was the students have to come one by one then read sentences from the song.

In Cycle two, the researcher distributed the song lyrics consist of a piece of paper entitled Insha Allab by Maher Zainas a learning process in improving pronunciation. The researcher played the song through audio, which aimed at the students to know the pronunciation of the song from the singer and make it easier for students to practice the lyrics. The students saw the lyric then the researcher asked the students to repeat the song together with karaoke version it aims to evaluate the extent to which students can imitate the pronunciation of the song.

After applying the media, the researcher believed that it can be applied in other classrooms to teach pronunciation. The teaching begins with the activity of guiding the students to sing a song and read the lyrics of the song. It helps the students to comprehend the lesson in the right order, increase the students' interest, and give valuable experience to the students, not only to develop their vocabulary but also to practice reading the lyrics and another simple word/sentence, as needed by $\mathrm{SMP} / \mathrm{MT}$ students.

\section{CONCLUSION}

Based on the result of reflection, it can be concluded that the use of songs in the English teaching and learning process could improve the students' pronunciation ability at MTs Almaarif 01 Singosari, Malang in cycle two with the song Insha Allah by Maher Zain and the score that was 71.16.

Based on the conclusion, the following on how to teach using songs. First, in choosing the song, the researcher must consider the difficulty level of the song. For the middle grade such as SMP/ MTs, the researcher can use and sing the song which is suitable and positive to them and also according to their age. Second, for the students choose a song that interesting and easy to hear for the learning media, it can make the students easily accept the songs, such as jazz, rock, and etc. Finally, the future researchers are suggested to conduct a similar study on using songs in a different context, subject, or method.

\section{ACKNOWLEDGEMENTS}

We would like to thank to all the authors who had already contributed to this paper and to the anonymous reviewers for their valuable comments.

\section{REFERENCES}

Castro, C.M.C. (2014). The use of English songs with social content as a situated literacy practice: Factors that influence students' participation in the EFL classroom.Ejournal, 125-138. doi: $10.17227 / 01234870.40$

Christamia, V. (2014).Improving student's speaking skills through English songs and puppets at grade IV of SD N Adisucipto II in the academic year of 2013/ 2014. (Published thesis).Yogyakarta State University.Yogyakarta, Jawa Tengah, Indonesia. Retrieved from https://eprints.uny.ac.id/18526/1/Veronica\%20Christamia\%2008202241021.pdf 
Dictionary.com. (2019).Dictionary.com: Lyric. Retrieved from http://spotidoc.com/doc/1168295/9chapter-ii-theoretical-review-and-conceptual.

Heslinga V. (2012). Theory and practice in language studies. Ejournal, 4 (2).

Lems, K. (2005). New ideas for teaching English using songs and music. English Teaching Forum.United States.

Manik, S. (2015).Improving students' pronunciation mastery by using english songs. Retrieved from https://uhn.ac.id/files/akademik_files/1712071010_2015_The $\% 20 \% 20$ Explora $\% 20 \% 20 \mathrm{Jo}$ urnal $\% 20 \% 20$ Journal $\% 20$ of $\% 20$ English $\% 20 \% 20$ Language $\% 20$ Teaching $\% 20$ (ELT) $\% 20$ and $\% 20$ Linguistics_5.\%20Improving $\% 20$ Students $\% 20$ Pronunciation $\% 20$ Mastery $\% 20 \mathrm{by} \% 20 \mathrm{Us}$ ing $\% 20$ English $\% 20$ Songs.pdf.

Merriam-Webster. (2019). Merriam-Webster:More definitions for pronunciation. Retrieved from https://www.merriam-webster.com/dictionary/pronunciation\#other-words.

Merriam-Webster. (2019). Merriam-Webster: Song.Retrieved from https://www.merriamwebster.com/dictionary/song.

Primandaru, M. (2013). Using songs to teach pronunciation to the fifth graders of SD nanggulan 1 kulonprogo.(Published thesis).Retrieved from https:// docplayer.net/63275230.html.

Samir, S.N. (2017). The use of total physical response (TPR) method in teaching pronunciation of command words at the second year of MTSN 408 binamujeneponto.(Published thesis).UinAlauddin Makassar. Makassar, Indonesia. Retrieved from http://repositori.uinalauddin.ac.id/4678/1/skripsi\%20jasmin.pdf

Sumantri, E. (2011). Improving students pronunciation by using English songs. (Published thesis).SyarifHidayatullah State Islamic University. Jakarta, Indonesia. Retrieved from http://repository.uinjkt.ac.id/dspace/bitstream/123456789/5623/1/ERNO\%20SUMANT RI-FITK

Yuningsih. (2018). An appraisal analysis : The interpersonal meanings in the discourse of a lyric. EjournalGetsempena English education Journal (GEEJ), 2 (5) 